\title{
Peertechz
}

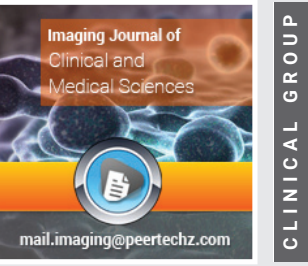

\section{COVID-19, Time to Change}

\section{Course}

\section{Olen R Brown*}

Professor Emeritus, Dalton Research Center, University of Missouri, Missouri 65201, USA

Received: 27 November, 2020

Accepted: 21 January, 2021

Published: 22 January, 2021

*Corresponding author: Olen R Brown, PhD, Professor Emeritus, Dalton Research Center, University of Missouri, Missouri 65201, USA,

E-mail:browno@missouri.edu

https://www.peertechz.com

Check for updates
Nearly one year ago the world awoke to a new disease, COVID-19. National economies and the lives of almost every individual on the planet Earth were directly impacted. The initial political and medical successes were to "flatten the curve" with social distancing, wearing masks and "lockdown" of society, and then to race toward a safe and effective vaccine. Two vaccines have now been developed and approved in the United States and one in England.

The measures used to control the spread of COVID-19 have been moderately effective but have resulted in dramatic and undesirable effects on social behaviors and national economies. The psychological negative effects, especially from changes affecting education from kindergarten through college, are significant but poorly understood. For a full recovery, a return to normal as rapidly as possible is essential.

Now is the time and there is the opportunity to shift gears. We know more now than at the start of the pandemic including that the seriousness of COVID-19 disease is strongly related to age and co-morbidities with effects that range from "asymptomatic" to death [1]. We have data that antibodies produced against COVID-19 are protective. The prospect of a world with herd immunity by vaccination may be within reach but requires time.

Also, advances make realistic the prospect of a rapid, inexpensive antigen test for COVID-19 infection that could be done by the individual and read with an app by a smart phone $[2,3]$. For example, technology is becoming available to allow the individual to use saliva as a sample for testing with results read by a smart phone. It is realistic to have results displayed as evidence of the status of the individual. There is enormous potential for collecting data that will require regulation.

Think about the effect of this test on the harmful aspects of societal lock-down. Why is it useful and necessary to avoid work, recreation, church, air travel, or family gatherings by individuals with a currently negative test for the virus? Quarantine is needed only for those who are shedding the virus that causes COVID-19. If purchasing a ticket is currently acceptable and required to board a plane or attend a concert why should society not accept a requirement for a current negative test on a smart phone to avoid "lock down"?

\section{References}

1. Brown OR (2020) Asymptomatic COVID-19; We Don't Know What We Don't Know. 1. Link: https://bit.ly/2NfZLml

2. NSF-funded Smartphone COVID-19 Diagnostic Test Could Put Testing in the Hands of the Public. BioSpace. Link: https://bit.ly/390C6kV

3. Duong T (2020) Affordable, Self-Administered COVID-19 Tests Could Use Your Cell Phone. EcoWatch. Link: https://bit.ly/39Ndmd2

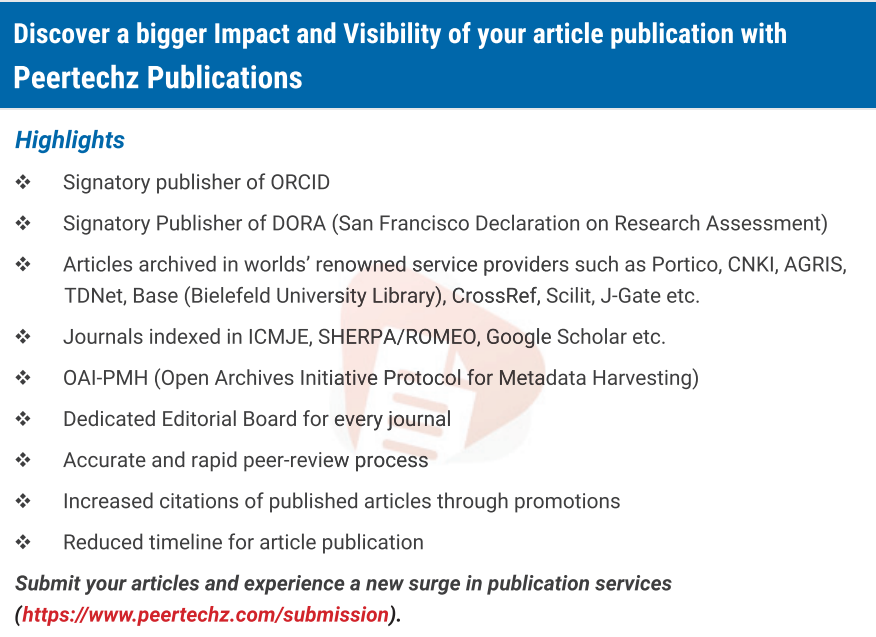

Peertechz journals wishes everlasting success in your every endeavours

Copyright: ๑ 2021 Brown OR. This is an open-access article distributed under the terms of the Creative Commons Attribution License, which permits unrestricted use, distribution, and reproduction in any medium, provided the original author and source are credited. 